\begin{tabular}{rr} 
çağdaş & Yaratıcı Drama Dergisi 2017, 12(1), 69-86 \\
drama & www.yader.org \\
\hline
\end{tabular}

\title{
Dördüncü Sanayi Devriminin Eşiğinde Yaratıcılık, İnovasyon ve Eğitim İlişkisi*
}

\begin{tabular}{|c|c|}
\hline \multicolumn{2}{|r|}{$\begin{array}{l}\text { Serkan Keleşoğlu' } \\
\text { Nurdan Kalaycı }\end{array}$} \\
\hline Makale Bilgisi & Öz \\
\hline DOI: $10.21612 /$ yader.2017.004 & $\begin{array}{l}\text { Dünya yeni bir sanayi devriminin içinden geçmektedir. Bu devrim ile üretimdeki } \\
\text { insan etkisi rol değiștirmekte ve yerini robotlara, ıșıksı fabrikalara bırakmaktadır. }\end{array}$ \\
\hline Makale Geçmişi & Bu gelişmelere dayalı olarak 21. yüzyılda eğitim sistemlerinin bireyleri farklı bilgi, \\
\hline Geliş tarihi & beceri ve değerlerle donatmasi gerekmektedir. 21. yüzyıl becerileri olarak tanımlanan \\
\hline 25.04.2017 & $\begin{array}{l}\text { bu özelliklerin başında yaratıcılık ve inovasyon gelmektedir. Inovasyon son yıllarda } \\
\text { toplumun bütün alanlarında kullanılan popüler sözcüklerden birisi haline gelmistir. }\end{array}$ \\
\hline 15.05.2017 & $\begin{array}{l}\text { Türkçe ye "yenileşim” olarak çevrilmesine rağmen bu çevirinin, kavramı tam olarak } \\
\text { karşılamadığı eleştirileri bulunmaktadır. Bu durum kavramın yanlış algılanmasına }\end{array}$ \\
\hline Anahtar Sözcükler & ve kavram yanılgısının yayılarak kavramın önemsizleşmesine yol açmaktadır. Oysaki \\
\hline $\begin{array}{l}\text { Dördüncü Sanayi Devrimi } \\
\text { Inovasyon }\end{array}$ & $\begin{array}{l}\text { inovasyon insanlığın gelişimi için yalnızca ekonomi alanına değil insanlıkla ilgili } \\
\text { tüm alanlarda yer alması gereken bir kavramdır. Bu çalı̧̧manın amact, yaratıcılık, } \\
\text { inovasyon ve eğitim ilişkisini ortaya koymaktır. Araştırmada alan yazın taraması }\end{array}$ \\
\hline Yaratıcllık & yapılmış, inovasyon kavramı tanımlanmış eğitimde inovasyonun nasıl uygulandiğı \\
\hline Ĕgitim & $\begin{array}{l}\text { ya da uygulanabileceği örneklendirilmiştir. Ekonomik gelişmelerden doğrudan } \\
\text { etkilenen eğitim alanının özellikle sosyal inovasyonu ön plana çıkarması gerektiği } \\
\text { önerilmektedir. }\end{array}$ \\
\hline \multicolumn{2}{|c|}{$\begin{array}{l}\text { On the Threshold of the Fourth Industrial Revolution, } \\
\text { Innovation and Education Relationship }\end{array}$} \\
\hline Article Info & Abstract \\
\hline DOI: $10.21612 /$ yader.2017.004 & $\begin{array}{l}\text { The world passes through a new industrial revolution. With this revolution, human } \\
\text { influence in production is changing roles and leaving its place to robots, the factory }\end{array}$ \\
\hline Article History & without light. Based on these developments, in the 21 st century, education systems \\
\hline 19.03.2017 & $\begin{array}{l}\text { need to equip individuals with different knowledge, skills and values. Creativity and } \\
\text { innovation are at the beginning of these characteristics, which are defined as } 21 \text { st }\end{array}$ \\
\hline 25.04 .2017 & century skills. In recent years, innovation has become one of the popular words \\
\hline 15.05.2017 & $\begin{array}{l}\text { used in all areas of society. Although translated as "innovation" in Turkish, this } \\
\text { translation has criticism that it can not fully meet the concept. This situation leads }\end{array}$ \\
\hline Keywords & $\begin{array}{l}\text { to the misconception of the concept and to the dissimilarity of the concept, which } \\
\text { leads to an insignificance of the concept. Innovation, on the other hand, is a concept }\end{array}$ \\
\hline 4th Industrial revolution & that must be included in all areas of humanity, not just in the field of economy, for the \\
\hline Innovation & development of mankind. The purpose of this study is to demonstrate the relationship \\
\hline Creativity & been done and it is exemplified how innovation can be applied or applied in education \\
\hline Education & $\begin{array}{l}\text { defined as the concept of innovation. It is suggested that the education area, which } \\
\text { is directly affected by economic developments, should bring social innovation in the } \\
\text { forefront. }\end{array}$ \\
\hline
\end{tabular}

* $\quad$ Bu makale Serkan Keleşoğlu tarafindan 2017 yılı Ocak ayında Prof. Dr. Nurdan Kalaycı danışmanlığında tamamlanan “Öğretmen Eğitiminde Yaratıcı Düşünme ve İnovasyon Eğitim Programı Tasarımı, Denenmesi ve Değerlendirilmesi” başlıklı doktora çalışmasından üretilmiştir.

1 Arş. Gör, Dr., Ankara Üniversitesi Eğitim Bilimleri Fakültesi, E-posta: skelesoglu1907@gmail.com

2 Prof. Dr., Gazi Üniversitesi Gazi Eğitim Fakültesi, E-posta: kalayci@gazi.edu.tr 


\section{Giriş}

Tolstoy, “İnsan Neyle Yaşar?” adlı kitabında insanın neyle yaşayacağı sorusuna birden fazla yanıt vermiştir. Bu sorunun kişiden kişiye değişen birden fazla doğru yanıtı bulunmaktadır. İnsan kimi zaman mutluluktan kimi zaman da başarıdan, paradan, itibar veya şöhretten beslenerek yaşamıştır. İnsan ne ile yaşarsa yaşasın temel kaygısı her zaman yaşamak, yaşamaya çalışmak olmuştur. İnsanlığın varoluşundan 21. yüzyılda gelinen noktaya kadar insanoğlu yaşamını en iyi şartlarda devam ettirilebilmek için karşılaştı̆̆ sorunları çözmeye çalışmış ve doğayı kendi yaşam standartlarını yükseltecek biçimde tasarlamıştır. Gerek teknolojik ürünler olsun, gerekse sanat eserleri olsun insanoğlu her zaman üretmiştir ve üretme, kendini ifade etme gereksinimi hissetmiştir. $\mathrm{Bu}$ üretim sürecinin temelinde ise her insanda var olan yaratıcılık ve yaratıcı düşünme becerisi yatmaktadir.

Yaratıcılık kavramı tanımlanması zor bir kavramdır. Farklı görüşlerin yaratıcılığı farklı biçimde tanımlamış olması nedeni ile alanyazında üzerinde ortak karar verilmiş bir tanımı bulunmamaktadır. Yaratıcılık kavramının Batı dillerindeki karşılığı "Kreativitaet, creativity" dir. Latince "creare" sözcüğünden gelen bu sözcük, "doğurmak, yaratmak, meydana getirmek anlamına gelmektedir (San, 2008). Sözcük anlamı incelendiğinde yaratma süreci sonunda ortaya yeni bir fikir, düşünce ya da ürün çıkarmak söz konusu olduğu görülmektedir. Uluslararası literatürde yaratıcılık üzerine çalışmaları ile ünlü kişilerden birisi olarak Torrance (1995) yaratıcılığı; rahatsız edici boşlukların veya eksik ögelerin farkına varma, bunlarla ilgili düşünme, varsayımlar ortaya atma, varsayımları sınama, elde edilen sonuçlara göre gerekirse yeni varsayımlar kurma, sorunlaraaksaklıklara, bilgi eksikliklerine, kayıp ögelere duyarlı olma, güçlülüğü tanımlama, güçlülüğe çözüm bulma ve tahminde bulunma olarak tanımlamaktadır. Yaratıcılık kavramı çoğunlukla bilimsel buluşları ya da önemli sanat eserlerini çağrıştırmakta olmasına rağmen yaratıcılığa, ailede veya iş yaşantısında çözüm bulunamayan problemleri çözme konusunda da gereksinim duyulur (Lau, 2011). Eğer insan yaratıcı olmasaydı ve yaratıcı düşünme becerisini etkili olarak kullanmasaydı yaşamını hala avcılık ve toplayıcılıkla sürdürmeye devam ediyor olabilirdi.

21. yüzyılda dünya artık uyumamaktadır! İnsanlığın değişimin hızını yakalamakta zorlandığı, zaman kavramının daha fazla önem kazandığı bir yüzyıl yaşanmaktadır. Bundan 50 yıl öncesine kadar insanlar, gece uyuduklarında dünyanın diğer bölgelerinde neler yaşandığını, gerçekleşen değişimlerin yaşamlarına nasıl etki ettiğini haftalar, aylar belki de yıllar sonra fark edibiliyordu. Şu an uykuda fazladan geçirilen bir saniye bile toplumların, teknolojik değişimin gerisinde kalmasına neden olabilmektedir. Özellikle teknolojik değişim mola vermemekte ve bu zamana kadar olduğundan daha hızlı yol almaktadır.

Robinson (2008) değişimin hızını; "Geçmiş 3000 yılı bir saat olarak kabul ettiğimizde ve her bir 60 dakikanın 50 yıla denk geldiği düşünüldüğünde üç dakika önce içten yanmalı motor; iki dakika önce motorlu araba; bir dakika önce roket gücü; 50 saniye önce uzay yolcuğu ve 10 saniye önce de yeniden kullanılabilir uzay mekiği icat edilmiştir." şeklinde somutlaştırmaktadır. Her ne kadar bu örnekler endüstriyel teknoloji alanında da olsa ekonomik değişimler toplumsal yaşamın bütün alanlarını derinden etkilemektedir. Özellikle eğitim sistemleri, ekonomik sistemin gereksinim duyduğu insan gücü potansiyelini karşılamak amaçlarından birine sahip olduğu için değişimlerin merkezinde yer almıştır. Sanayi devrimlerinin gerçekleşmesinin temelinde problem çözme, eleştirel ve yaratıcı düşünme gibi üst düzey düşünme becerileri yatmaktadır. Yaratıcı düşünme becerisi Jules 
Verne'e “Aya Yolculuk” kitabını yazdırmış, Astronot Neil Armstrong'a bu düşü gerçeğe dönüştürme firsatı vermiştir. 1969 yılında insanlık için büyük bir adım olarak nitelendirilen "aya ayak basmanın”, 2020'li yıllarda uzay turizmi sektörünün faaliyete geçmesi ile insanlık için sıradan bir eylem halini alması planlanmaktadır. Bu sektörün ortaya çıkması yeni iş alanlarını getirecek ve zaman, şu an var olan birçok mesleği de tarihin tozlu sayfalarına ya da müzelere hapsedecektir. Bu bağlamda "Eğitim sistemindeki öğrencilerin mezun olduklarında yapacakları işler bile henüz var olmamıştır" denilebilir (Partnership for 21st Century Skills, 2016).

İnsanlık bugüne kadar üç endüstriyel devrim yaşamıştır ve şu an dördüncü devriminin içinde bulunmaktadır. 2020'li yıllarda toplumlar yeni bir teknolojik, ekonomik ve sosyal dönüşümün eşiğindedir. Bilişim teknolojilerini ve endüstriyi bir araya getirmeyi amaçlayan dördüncü sanayi devriminin endüstriyel strateji planı, 2011 yılında Almanya'da gündeme gelmiştir (Wikipedia, 2016). Her endüstri devriminde olduğu gibi toplum yaşamı bu devrimden de etkilenecek ve eskiye ait bazı bilgi ve beceriler yer değiştirecektir. Günümüz dünyasında bilgi üretimi astronomik düzeydedir ve kimse bu bilgi birikimini edinebilecek, bu bilgilerin doğru ya da yanlışlığını ortaya koyabilecek yeterlilikte olamayacaktır. 21. yüzyılda çok fazla bilgiye sahip olan değil; karşılaştığı sorunu çözebilecek bilgiye ulaşabilen, kendi kendine öğrenebilen, sorunlara yaratıcı çözümler bulabilen bireyler ayakta kalabilecektir.

Dünya Ekonomik Forumu'na göre (World Economic Forum, 2016) 2020 y1lında dördüncü sanayi devriminin gerçekleşmesi ile en önemli on becerinin şu şekilde değişmesi öngörülmektedir.

Tablo 1. 2015 ve 2020 Ylllarinda En Önemli On Beceri Listesi

\begin{tabular}{ll}
\hline $\mathbf{2 0 2 0}$ Yılında & $\mathbf{2 0 1 5}$ Yılında \\
\hline 1. Karmaşık Problemleri Çözebilme & 1. Karmaşık Problemleri Çözebilme \\
\hline 2. Eleştirel Düşünme & 2. İşbirliği \\
\hline 3. Yaratıcılık & 3. İnsan Yönetimi \\
\hline 4. İnsan Yönetimi & 4. Eleştirel Düşünme \\
\hline 5. İşbirliği & 5. Münazara \\
\hline 6. Duygusal Zeka & 6. Kalite Kontrol \\
\hline 7. Değerlendirme ve Karar Verme & 7. Hizmet Odaklılık \\
\hline 8. Hizmet Odaklılık & 8. Değerlendirme ve Karar Verme \\
\hline 9. Münazara & 9. Aktif Dinleme \\
\hline 10. Bilişsel Esneklik & 10. Yaratıcılık \\
\hline
\end{tabular}

(2015 ve 2020 y1llarında en önemli on beceri listesi._https://www.weforum.org/agenda/2016/01/the-10-skil1s-you-need-to-thrive-in-the-fourth-industrial-revolution/ sayfasından erişilmiştir).

Gelecek beş y1l içinde listenin ilk sırasında bir değişiklik beklenmezken eleştirel düşünme ve yaratıcılık becerilerinin üst sıralara taşınacağ öngörülmektedir. 21. yüzyılda yaşayan bireylerin kazanması beklenen bu beceriler bazı alanlarda "21. yüzyıl becerileri” olarak adlandırılmaktadır. Ancak bu beceriler çok geniş bilgi ve farklı alt becerileri kapsadığı için alan uzmanlarının üstünde uzlaşabildikleri bir liste bulunmamaktadır. Bu becerileri tanımlamak ve kategorileştirmek çok kolay bir iş değildir. Bu nedenle bu becerilerin tanımlanması okuldan okula, kişiden kişiye farklılık göstermektedir (P21, 2016). 
21. yüzyıl becerilerini üç ana başlık altında 13 beceri olarak almışlardır (P21'den aktaran Ery1lmaz ve Uluyol (2015).

Tablo 2. 21. Yüzyll Becerileri

\begin{tabular}{|c|c|}
\hline Beceri & Alt Beceri \\
\hline \multirow{5}{*}{ Öğrenme ve Yenilikçilik Becerileri } & Yaratıcı Düşünme \\
\hline & Eleştirel Düşünme \\
\hline & Problem Çözme \\
\hline & İletişim \\
\hline & İşbirliği \\
\hline \multirow{3}{*}{ Bilgi, Medya ve Teknoloji Becerileri } & Bilgi Okuryazarlığı \\
\hline & Bilgi ve İletişim Teknolojileri (BİT) Okuryazarlığ1 \\
\hline & Medya Okuryazarlığ 1 \\
\hline \multirow{5}{*}{ Yaşam ve Kariyer Becerileri } & Esneklik ve Uyum \\
\hline & Kendini Yönetme \\
\hline & Sosyal Beceriler \\
\hline & Üretkenlik ve Hesap Verebilirlik \\
\hline & Liderlik \\
\hline
\end{tabular}

Wagner (2008); eleştirel düşünme ve problem çözme, işbirliği ve liderlik, esneklik ve uyum, girişimcilik, etkili sözel ve yazılı iletişim, bilgiye erişme ve analiz edebilme ile merak ve hayalgücü becerilerinin öğrencilerin gereksinim duydukları önemli beceriler olduğunu ifade etmektedir. $\mathrm{Bu}$ becerilerin son dönemde ortaya çıkmadığı yıllardır eğitim sistemlerinin bireylere kazandırmayı amaçladığ 1 beceriler arasında yer aldığı söylenebilir.

Atc21s (21. yüzy1l becerileri öğretimi ve değerlendirilmesi), 21. yüzyıl becerilerini dört kategori altında toplamaktadır. Düşünme yolları kategorisinde; yaratıcılık ve inovasyon, eleştirel düşünme, problem çözme, karar verme; öğrenmeyi öğrenme/üst biliş becerilerine yer vermiştir. Günümüzde yaratıcılık, medeniyetin gelişmesini sağlayan itici bir güç olması nedeniyle eğitim sistemleri tarafından geliştirilmesi gereken yaşamsal öneme sahip becerilerden biri olarak değerlendirilmektedir (Craft, 2007); çünkü ekonomik, sosyal, politik birçok soruna çözüm bulma potansiyelini barındırmaktadır (Aish, 2014; Burnard \& White, 2008; Kampylis, 2010).

21. yüzyıl becerilerinin başında insanlığın varoluşundan bu yana önemini koruyan yaratıcı düşünme becerisi, ekonomik sistemlerin tetikleyicisi olarak da görülmektedir. Florida (2006) varolan ekonomik sistemi daha ileri taşıyabilecek anahtar etmen yaratıcılık olduğu için bu dönemi "yaratıcılık çağı" olarak nitelendirmektedir. Yaratıcılık, yeni iş alanları ortaya çıkardığı, sosyal ve bireysel olarak güdüleyici olan inovasyonun çıkış noktası olduğu için ekonomik, toplumsal ve küresel çevrelerde de ödüllendirilmektedir. Günümüzde politik ve ekonomik mücadeleler öğrencilerin daha iyi problem çözebilen ve yaratıcı inovatörler olmalarını beklemektedir (Pacific Policy Research Center, 2010).

Yaratıcı düşünmenin yanı sıra ön plana çıkan diğer bir kavram ise inovasyondur. Schumpeter inovasyonu dar anlamda, yeni bir üretim fonksiyonu geliştirmek olarak tanımlamıştır. Geniş anlamda ise inovasyon; yeni bir ürün icat etmek, yeni bir üretim yöntemi geliştirmek, yeni bir pazar kurmak, hammadde temini için yeni kaynaklar geliştirmek ve yeni bir organizasyon oluşturmak gibi faaliyetleri kapsamaktadır (Schumpeter'den aktaran Işık \& Kılınç, 2012). 
Geçen 20-30 y1l içinde imalata dayalı ekonomi, bilgiye ve inovasyona dayalı bir hizmet ekonomisine doğru değişmiştir. İnovasyon; küresel problemlerin çözülmesine yardım eden, yeni üretim teknikleri geliştiren, verimliliği artırıcı hizmetleri geliştiren, yeni istihdam olanakları sağlayan, yurttaşların yaşam kalitelerini artıran, yeni teknolojileri ve yeni ürünleri beraberinde getiren ve bu özellikleriyle ekonomik büyüme sürecine ciddi katkılar sağlayan önemli bir faktördür (Shqipe \& Ramadani, 2010). Ayrıca inovasyon; toplumların, bireylerin yaşam standartlarına ve sosyal refaha da olumlu katkılar yapmaktadır (Uzkurt, 2008).

Amerika Birleşik Devletleri Ulusal İnovasyon Girişimi (National Innovation Initiative), 2004 Aralık ayında "Innovate America" başlıklı raporunda, 21. yüzyılda Amerika'nın başarısının belirlenmesinde tek ve en önemli faktörün inovasyon olacağını belirtmiştir (Ersöz, 2009). Dünya Bankası tarafından 2007 yılında gelir düzeyi ile inovasyon arasındaki korelasyona yönelik olarak yapılan çalışmada; ABD, Danimarka, İrlanda, ve İsveç gibi ülkelerde inovasyon endeksi ile gelir düzeyi arasında pozitif bir ilişki olduğu saptanmıştır (Işık \& Kılınç, 2012).

Dünya Ekonomik Forumu tarafından yayınlanan 2012-2013 Küresel Rekabet Raporu'nda, ülkeler gelişme aşamalarına göre; ekonomik anlamda kalkınmanın en üst aşamasındaki ülkeler, inovasyon tarafından yönlendirilen inovasyon-güdümlü; en alt aşamasındaki ülkeler ise doğal kaynak zenginliklerine dayalı faktör-güdümlüdür. Geriye kalan ülkeler ise gelişmiş ülkelerle ekonomik ilişkilere dayalı bağımlılık modelini uygulayan ülkelerdir (Işık \& Kılınç, 2012). İnovasyon konusundaki araştırmalar, ülkelerin inovasyon performanslarındaki artışın ekonomik ve toplumsal kalkınma, refah ve gelişme için anahtar rol oynadığını; bilgi ekonomisine geçiş için en önemli itici güç olduğunu; etkin inovasyon politikalarına ve sistemlerine sahip ülkelerin gelişmişlik yarışında hızla ilerlediklerini, inovasyon sayesinde eşitsizlikler de dâhil olmak üzere pek çok toplumsal sorunun üstesinden gelmeyi başardıklarını açıkça ortaya koymaktadır (Elçi, 2009).

İnovasyon kavramının ilk olarak iktisat alanında tanımlanması ve "değer taşıyan yenilik" olarak algılanması nedeniyle eğitim alanında üzerine çalışılan bir kavram olarak görülmemekte ya da yalnızca "yenilik" olarak algılanması nedeniyle kullanılmamaktadır. Oysaki eğitim programlarının geliştirilmesi, öğretmenlere yönelik hizmet içi eğitimler, yeni öğretim yöntem ve tekniklerinin öğrenci başarısı üzerinde etkisinin ölçülmesi, okul binalarının, sınıflarının öğrencilerin psikolojik özelliklerine göre düzenlenmesi vb. birçok çalışma aslında eğitimde inovasyona yönelik örneklerdir.

Eğitimciler iktisat kökenli bu sözcügün anlamının eğitim sistemini de bir fabrika gibi algılanmasına neden olacağını düşünerek yalnızca yenilik olarak kullanmayı tercih ediyor olabilirler. Yamaç (2001) OECD’nin inovasyon tanımı açısından; amacın, yapılan yenilenmelerin, buluşların ticari yarara dönüşmesi ve pazarlanması söz konusu olacağı için eğitimde inovasyon değil yenilenme veya reformdan bahsetmenin daha doğru olacağını ifade etmektedir.

İnovasyon, eşitsizliklerin ortadan kaldırılmasında da en önemli araçların başında gelir. Birleşmiş Milletlerin Milenyum Projesi kapsamında yürütülen çalışmalar, iyi bir bilim, teknoloji ve inovasyon politikası olmadan sağlık ve çevre alanlarında ilerlemenin mümkün olmayacağını ortaya koymaktadır. Aynı şekilde, iyi hazırlanmış ve başarıyla uygulanan inovasyon politikası, eğitim, kadın-erkek eşitliği ve yaşam şartlarının iyileştirilmesi konularında büyük kazanımları beraberinde getirmektedir (Elçi, 2009).

Eğitimde 21. yüzyıl öğrenme reformu hareketi, eğitimsel organizasyonların sosyal değişimde daha fazla sorumluluk üstlenmesi ve dünyadaki ekonomik düzenin devam ettirilmesi için gereken 
katkıları yapabilecek eğitim hizmetlerini desteklenmesini talep etmektedir. Bu nedenle ekonomik rekabette geri kalmak istemeyen politika yapıcılar eğitim sistemine büyük önem vermekte ve inovatif eğitim sistemlerine kaynaklar ayırmaktadırlar (Lubienski, 2009).

Her bir eğitim süreci sonucu itibariyle bir üretim ya da geliştirme sürecidir. Eğitim programlarının hedefleri ve amaçları doğrultusunda öğrenciye kazandırılması beklenen özellikler, nitelikler, beceriler bulunmaktadır. Teknolojideki hızlı gelişmelere ve bu gelişmelerin toplum üzerindeki önemli etkilerine rağmen eğitim sisteminde yenileşmeyi düşünmemek yaşamdan kopuk ve -mış gibi yapılan bir duruma dönüşmektedir. Bu durum eğitim sisteminde inovasyon uygulamalarının yapılmasını zorunlu kılmaktadır.

Gelişmiş ekonomik büyüme isteyen çoğu ülkenin ulusal eğitim politikaları aşağıdaki temalar etrafinda siralanmaktadır (Bentley, 2008):

- Temel sonuçlarda, özellikle de aritmetik ve okuma-yazmada düzeyi geliştirmek için standartlara dayalı stratejiler,

- Temel performans göstergelerine dayalı raporlama, değerlendirme ve hesap verilebilirlik için çerçeveler,

- Okul binalarının modernizasyonu, bilgi iletişim teknolojileri donanımı ve ağ altyapısını da kapsayan yeni alt yapı,

- Sınıfların azaltılması ve yeni öğretmenlerin eğitimi,

- Yüksek performanslı eğitim liderlerinin tespiti, eğitilmesi ve ödüllendirilmesi,

- Yükseköğrenimi genişleterek, yeni okul-iş yolları ve yüksek mesleki nitelikler yaratarak zorunlu eğitim sonrasına katılımın arttırılması,

- Eğitim iş gücünü; esneklik, mesleki gelişim, mesleki uzmanlık ve yardımc1 personelin rollerinin belirlenmesi, performans yönetimi konularına önem verecek yönde şekillendirmek,

- Gençler arasında sivil dayanışma ve vatandaşlık duygusunu geliştirme,

- Özel ve yoksun sosyal guruplar ve kentsel veya kırsal alanlardaki uç gruplar arasındaki düşük performans ile mücadele etmek.

Avrupa'daki eğitim sistemleri ile karşılaştırıldığında, AB üyeliğini hedefleyen ülkemizde kamu okullarının kaynaklar, okul personelinin görevlendirilmesi, ders kitabı seçimi, öğretim zamanının tahsisi, öğretilecek programların seçimleri konularında en az özerkliğe sahip olduğu görülmektedir (Çınar vd. 2009). Bu durum eğitim ile ilgili inovasyonların daha çok ders anlatımları üzerinde şekillenmesine sebep olmaktadır.

Ulusal inovasyon sisteminin önemli ayaklarından biri olan MEB, inovasyon kültürünün oluşması için öğretim programlarında; yaratıcı düşünme ve girişimcilik becerisini temel beceriler olarak Teknoloji ve Tasarım dersi içerisinde yer vermiştir. Öğretim programında inovasyon; daha önce çözülmemiş sorunları çözmeye ya da karşılanamamış çözümlere yanıt olan farklı değişik, yeni fikirler geliştirmek ve bunları uygulamak ya da var olan ürünlerin veya hizmet sürecinde yeni yöntemlerin uygulanmaya başlaması ile inovasyonun yapılabileceğini ifade etmektedir (MEB, 2009). 
Türkiye'de eğitimde inovasyon uygulamaların 2004 y1lından itibaren özellikle eğitim programlarının geliştirilmesi boyutunda gerçekleştiği görülmektedir. Ancak merkezi olarak geliştirilen öğretim programlarının okullarda ne kadar etkili olabildiğine ilişkin soru işaretleri bulunmaktadır. Bu durum inovasyon kaynaklarının sorgulanmasını gerektirmektedir.

\section{İnovasyon}

21. yüzyılda teknolojik gelişmelere paralel olarak yeni sorunlar ortaya çıkmakta ve bu sorunların da hızlı, yaratıcı ve değer içeren bir biçimde çözülmesi gerekmektedir. Bu sorunlar bir telefon kamerasının çözünürlüğünün arttırılmasından, fosil yakıtlı tükenen enerji kaynaklarına alternatif yenilebilen enerji kaynaklarından en yüksek düzeyde yararlanabilmeyi sağlayacak araçların geliştirilmesine kadar geniş bir yelpazede dağılım göstermektedir. İnsanların sorunlara çözüm bulmaları ve buldukları çözümleri insanlığın kullanımına sunmaları aynı süreçlerin başka kişiler tarafından tekrar denenmemesini sağlayacaktır. Bu durum geçmişten bugüne kadar da aynı biçimde devam etmiştir. Örneğin, "yerçekimi” dünyanın oluşumu ile ortaya çıkmış bir olgudur. Bu olgu 17. yüzyıla kadar yüzlerce kişi tarafından fark edilmiş olabilir ancak 1687'de Newton'un 'Philosophi Naturalis Principia Mathematica" (Doğa Felsefesinin Matematiksel İlkeleri) adlı kitabı ile bilimsel olarak yayınlanmış ve bilim tarihindeki yerini almıştır. Newton'un çalışmaları Einstein'ın teorilerinin temelini oluşturmuştur. Tarihte bu örneğe benzer daha birçok örnek yer almaktadır. Bu örnekler yaratıcı düşünme becerisinin hayata geçirilmesi gerekliliğini ön plana çıkarmaktadır. Bu durum 21 . yüzyılda "inovasyon” kavramının önemini arttırmıştır.

İnovasyon, yaratıcılık kavramına eşdeğer bir kavram görülmektedir. Özellikle sosyoloji alanında inovasyon kavramı yaratıcılık sözcüğünün yerine kullanılmaktadır. Yaratıcılık ve inovasyon kavramlarının birbirine yakın kavramlar olmasına rağmen tam olarak aynı anlama geldikleri söylenemez. İnovasyonun gerçekleşmesi için bir yaratıcı sürecin olması gerekmektedir ancak her yaratıcı süreç parasal bir değere dönüşmek ya da dönüştürülmek zorunda değildir. Yaratıcılık tanımı ve çalışmaları ile tanınan Amabile (1997) yaratıcılı̆̆ın inovasyona giden ilk adım olduğunu ve inovasyonun, yaratıcı fikirlerin başarılı bir biçimde uygulanması olduğunu ifade etmektedir. Yaratıcılık bireysel, inovasyon ise bir takım çalışmasıdır. İnovasyon süreci yaratıcı bir fikre dayanan bir gereksinim ile başlar (Tanner, 1994). Yaratıcılık bilişsel bir süreç iken inovasyon sosyal bir süreçtir (Rank vd, 2004).

İnovasyon sözcüğü son günlerde önem kazanmış olmasına rağmen sözcüğün geçmişi 16. yüzyıl İngiltere'sine dayanmaktadır (Zeren, 2010). İnovasyon kavramı kökü Latince olan ve yeni bir fikir, tasarım, ürün vb. ya da yeni bir ürünün, tasarımın ya da fikrin geliştirilmesi anlamına gelmektedir (Cambridge, 2016). Kavram, Türk Dil Kurumu (TDK) tarafından Türkçe 'ye "yenileşim" olarak tercüme edilmiştir (TDK, 2015). TDK 'nın yapmış olduğu tanımlamanın çok kısıtlı ve yetersiz kaldığı iddia edilmektedir (Elçi, 2009). Yenileşim sözcüğünün yenilikten ya da yeni olandan farkının ne olduğu anlaşılamamaktadır. Bu tanıma göre yeni olan her şey inovasyon olarak kabul edilebilir. Kavramın bu kadar geniş uçlu tanımlanmış olması yaratıcılık kavramında olduğu gibi kavramın bilinçsiz ve anlamı dışında kullanılması sorununu da beraberinde getirmektedir. Kırım (2006); yenilik ve inovasyon arasındaki farklılı̆ga vurgu yaparak, her yeniliğin inovasyon ile eşit sayılamayacağını, yeni olanın inovasyon sayılabilmesi için piyasada farklı bir değer edinmesi gerektiğini vurgulamaktadır. 
İnovasyon kavramı 1911 yılında Schumpter tarafindan "ekonomik kalkınmanın itici gücü” olarak tanımlanmıştır. İnovasyon, OECD ve Avrupa Komisyonu tarafından hazırlanan Oslo Kılavuzuna göre ise; "İşletme içindeki uygulamalarda, işyeri organizasyonunda ya da diş ilişkilerde, yeni veya önemli ölçüde iyileştirilmiş bir ürün ya da sürecin, yeni bir pazarlama yönteminin veya yeni bir organizasyonel yöntemin uygulanması" olarak tanımlanmaktadır (Adıgüzel, 2012; Baykal, 2007; Gürel, 2010; Karaca, 2011; Kavacık, 2012; Kurtuluş, 2012).

Yaratıcılık kavramının tanımlamasında olduğu gibi inovasyon kavramının tanımlanmasında da farklı bakış açıları bulunmaktadır. İnovasyon üzerine yapılan 76 tanımı inceleyen bir çalışmada kavram; a. Yeni bir parçanın geliştirilme sürecini, b. Yeni parçanın kendisini ve c. Yeni parçanın kullanım sürecini içeren kavramlarla ifade edilmektedir (Güleş \& Bülbül, 2004). Freeman (1982) inovasyonu; yeni bir ürünün ya da sürecin ticari bir biçimde kullanılması adına yürütülen; tasarım, üretim, yönetim ve ticari faaliyetlerin tümü olarak tanımlamaktadır (Aktaran Işık \& Keskin, 2013).

Roberts (1987); “İnovasyon = icat + kullanım. İcat, yeni fikirler yaratmak ve bunları işler hale getirmek için ortaya konan tüm çabaları ifade eder. Kullanım süreci, ticari geliştirme, uygulama ve transferi kapsar; belli hedeflere yönelik fikirlere ve icatlara odaklanmayı, bu hedefleri değerlendirmeyi, araştırma ve/veya geliştirme sonuçlarının transferini ve teknolojiye dayalı sonuçların geniş bir alanda kullanımını, yayılmasını ve yaygınlaştırılmasını da içine alır" (Aktaran: Elçi, 2009). TÜSİAD (2003), inovasyonu bir süreç olarak ele almış ve bilim ve teknolojiyi ekonomik ve toplumsal bir faydaya dönüştürmek olarak ifade etmiştir. Edvinson (2004) Roberts'in tanımına farklı bir yaklaşım getirmiş ve inovasyonu; teorik kavram + teknik yenilik + ticari uygulamalar olarak formüle etmiştir. Edvinson bu tanımı ile bilgiyi, yeniliği ve ticari boyutu bir araya getirmiştir. Wylant (2008) bir işletme modeli, organizasyon, sistem, davranış, ürün gibi bir probleme çözüm olacak yeni bir şeye ulaşma süreci olarak tanımlamaktadır.

Porter'a göre inovasyon (1990) hem teknolojide yeni gelişmeler hem de işleri daha iyi yapan yeni yöntemler ya da yollar sağlamak ve ürün değişimleriyle, süreç değişimleriyle, pazarlamaya yeni yaklaşımlarla, yeni dağıtım şekilleriyle ve yeni kapsam kavramlarıyla açıklanabilir (Aktaran; Baykal, 2007). Dosi (1998)'e göre inovasyon; bir keşif, deney, gelişim, taklit ve yeni ürünler, yeni üretim sistemleri ve yeni organizasyon kurumlarını içeren bir araştırma faaliyetidir (Aktaran; Kılınç, 2011).

İnovasyon en geniş anlamıla, bilginin ekonomik ve toplumsal faydaya dönüştürülmesi olarak tanımlanır. Bu nedenle de teknik, ekonomik ve sosyal süreçler bütünüdür. Değişime olan istek, yeniliğe açıklık ve girişimcilik ruhuyla özdeşleşen bir kültürün ürünüdür (Levesque \& Walker,'dan aktaran; Karabulut, 2009). İnovasyon için bilim ve teknolojide gelişmeler ve bu gelişmeleri sağlayacak alanında uzmanlaşmış insan gücüne gereksinim duyulmaktadır. İnsan gücünün yetişmesi ise ancak eğitim sistemi tarafından karşılanabilecek bir gereksinimdir. İnovasyon kavramı paraya dönüştürülen yenilik olarak tanımlanmakta ve ağırlıklı olarak ekonomi ile ilişkilendirilerek kullanılmaktadır (Kirım, 2009).

\section{İnovasyon Kaynakları}

Drucker (1998) dört tanesi içsel, üç tanesi dişsal olmak üzere toplam yedi tane inovasyon kaynağı belirlemiştir. Bu kaynakların tanımları ve eğitim sistemi ile ilişkisi şu şekilde açıklanabilir: 


\section{İçsel İnovasyon}

Drucker’a göre (1998) “beklenmeyen gelişmeler”, “uyumsuzluk durumu”, “süreç gereksinimleri” ve "sektör ve pazar yapısındaki değişmeler" olmak üzere dört çeşit içsel inovasyon kaynağı bulunmaktadır.

Beklenmeyen Gelişmeler: Beklenmeyen durumların benzersiz bir firsatın göstergesi olabileceği özellikle kriz anlarının inovasyon için önemli bir kaynak oluşturduğu düşünülmektedir. Örneğin; ülke bütçesinin fazla vermesi ve bu bütçenin eğitime aktarılmasıyla eğitimde istihdam olanağı artabilir. Sınıf mevcutları ideal sayılara çekilebilir. Bu durum derslik ve istihdam edilecek öğretmen sayısının artışını sağlayabilir ya da mesleğe yeni başlayacak öğretmenlerle deneyimli öğretmenler aynı sınıfta derse girebilirler. Öğretmenlerin daha profesyonel yetiştirilmesinde önemli bir adım olabilir.

Uyumsuzluk Durumu: Gerçek ile olması beklenen şey arasındaki çelişki, yenilikçi bir firsat yaratabilir. Örneğin; öğretim programları Milli Eğitim Bakanlığı tarafından Türkiye'deki bütün okul ortamları, öğrenci hazırbulunuşluğu, kaynaklara ulaşım şansı vb. ölçütleri ortalama aynı düzeyde olduğu düşünülerek hazırlanmaktadır. $\mathrm{Bu}$ durum uygulanması istenilen öğretim programı ile uygulanacağ1 okul ortamları arasında bir uyumsuzluk durumu oluşturmaktadır. Bu uyumsuzluğun ortadan kaldırılması için öğretmen özerkliğinin sağlanmasına yönelik inovasyonlar yapılabilir ya da okul ortamlarının öğretim programının uygulanabileceği şekilde desteklenmesi sağlanabilir.

Süreç Gereksinimleri: Bir sürecin düzeltilmeyen bir zayıf halkası yenilik için bir firsat yaratabilir. Türk eğitim sisteminde değerlendirme sistemi y1llardır eleştirilen bir sorun olarak durmaktadır. Bu sorunun çözümüne yönelik olarak çoktan seçmeli testlerin yerine farklı değerlendirme araçlarının uygulanması değerlendirme sisteminde önemli bir inovasyona kaynaklık edebilir.

Sektör ve Pazar Yapısındaki Değişmeler: Endüstri ya da pazar yapısındaki değişim, ürün, hizmet ve iş yaklaşımı konusunda çok sayıda inovasyon fırsatı yaratır. Örneğin; dördüncü sanayi devriminin gerçekleşmesi ile eğitim sistemlerinin yetiştirmesi beklenen birey profilinde değişimler zorunlu olmuştur.

21. yüzyıl becerilerini bireylere kazandırmayı amaçlayan öğretim programlarının geliştirilmesi sistemdeki değişikliğe bağlı olarak yapılmış inovasyonların başında gelmektedir.

\section{Dışsal Kaynaklar}

İnovasyonun ortaya çıkmasını sağlayan dışsal kaynaklar ise; demografik yapıdaki değişiklikler, algılamadaki değişiklikler ve yeni bilgi olmak üzere üç başlık altında toplanmaktadır.

Demografik Yapıdaki Değişiklikler: Nüfustaki, yaş yapısındaki, işsizlikteki, eğitim ve gelir seviyelerindeki değişime bağlı olarak bir inovasyon fırsatı doğabilir. Avrupa Birliği üye ülkelerinde yaş ortalamasının yüksek olması nedeniyle insanların iş yaşamındaki sürelerinin uzatılması için Yaşam Boyu Öğrenme kavramı önem kazanmış ve Erasmus gibi Avrupa Birliği değişim programlarına benzer birçok yeniliğe kaynaklık etmiştir.

Algılamadaki Değişiklikler: Belirli bir toplumun genel görüşleri, tutumları ve inançları değiştiğinde, inovasyon firsatları çıkabilir. Örneğin, Türkiye'de son yıllarda çocuk gelin sayısındaki artış ve kız çocuklarının eğitim almalarının önündeki engeller bu sorunları ortadan kaldırmaya yönelik toplumu bilinçlendiren ve farkındalık kazandıran projelerin gerçekleştirilmesini sağlarken, sivil toplum kuruluşlarının yaptıkları çalışmalar da bu alanda inovasyonları tetiklemektedir. 
Yeni Bilgi: Bilimsel, teknik ya da sosyal bilgideki değişim yeni ürün ve yeni pazar inovasyonları için firsat yaratmaktadır. Bu tür inovasyonlar tek bir bilgi türü yerine birden fazla bilginin bir arada kullanılmasına ihtiyaç duyabilirler (Drucker, 1998). Örneğin, son yıllarda nörobiyoloji, nöroeğitim alanındaki çalışmalar beynin çalışma prensiplerini belirlemede ve beynin gizeminin çözülmesinde yol almakta ve yeni bilgiler üretmektedir. Beynin sınırlarının çözülmesine yönelik çalışmalar ve bulgular bu alanda daha farklı çalışmaların gerçekleştirilmesine, beyin görüntüleme sistemlerinin yenilenmesine kaynaklık etmektedir. Bu alandaki yeni bilgi yapıları eğitim alanında bilişsel yaklaşımların ve bu yaklaşımlara uygun farklı inovasyonların zeminini hazırlamıştır.

Luecke (2008) ise inovasyonun altı temel kaynağı olduğunu ifade etmiştir.

Yeni bilgi: Bilim ve teknoloji ile iç içe olan inovasyon yeni bilgilerin üretilmesi ile sürekli bir döngü içerisindedir. Psikoloji alanında biliş üzerine yapılan çalışmalar sonucu elde edilen yeni bilgiler eğitim sistemlerinde inovasyonları zorunlu kılmaktadır.

Tüketici düşüncelerinden yararlanmak: Tüketiciler üründen doğrudan etkilenen kişiler olarak ürünün zayıf yönleri konusunda en iyi dönütleri verebilecek kitlelerdir. Örneğin; eğitim sisteminden doğrudan etkilenen öğrencilerin öğretim programlarına ilişkin ya da öğretmenlerinin derslerine ilişkin dönütlerinden öğrenme-öğretme süreçlerinde inovasyonlar gerçekleştirilmesine olanaklar sağlayabilir.

Lider Kullanıcılar: Pazardaki lider kullanıcılardan elde edilen dönütlerle ürünlerin geliştirilmesinde önemli bilgiler sağlayabilir. Örneğin; öğretim programlarının uygulayıcıları olan öğretmelerin çeşitli akademik çalışmalarla görüşlerinin toplanması öğretim programlarında gerçekleştirilebilecek inovasyonlara kaynaklık edecektir.

Empatik Tasarım: İnovasyon için çaba harcayan kişi ya da kurumların tüketicilerin sahip oldukları ürün ve hizmeti kendi çevrelerinde nasıl kullandıklarını gözlemleyerek fikir üretme yöntemidir. Bu duruma Amerika'da uygulanan "Lesson Study" uygulaması örnek verilebilir. Bu uygulama kapsamında bir grup öğretmen geliştirmiş oldukları materyallerin uygulama süreçlerinde öğrenci gibi yer alırlar ve öğrencinin gözünden süreci/materyali değerlendirirler. Uygulama sonrasında uygulayıcı olan öğretmen ile süreç/materyal üzerine tartışılır. Bu tartışma süreç ya da materyal için bir inovasyona temel oluşturabilir.

Yenilik Pazarı: Şirket dışı fikirlerden yararlanmak olarak ifade edilmektedir. Öğretmenlerin ulusal ve uluslararası kongre, sempozyum vb. faaliyetlere katılmaları farklı okullardaki uygulamalar hakkında bilgi sahibi olmalarına ve bu yenilikleri kendi okullarına ya da süreçlerine uygulamalarına yardımcı olabilmesi açısından kaynaklık edebilir.

Ticari bir kavram olmasına rağmen eğitim sistemi içinde de birçok inovasyon kaynağının yattığ 1 görülmektedir. Bu kaynakların dikkate alınması ve inovasyona çevrilmesi ise ancak bilinçli yöneticiler, öğretmenler, öğrenciler, akademisyenler ve politika yapıcılarla gerçekleşebilecektir. 


\section{İnovasyon Türleri}

Sternberg, inovasyonu yineleme, yeniden tanımlama, ileriye yönelik artırım, yüksek düzeyde ileriye yönelik artırım, yeniden yönlendirme, yeniden yapılandırma, yeniden başlatma ve bütünleştirme olmak üzere sekiz türe ayırmıştır (Stenberg'den akaran Kurtuluş, 2012). Oslo Kılavuzu' nda ise dört çeşit inovasyondan bahsedilmektedir. Bunlar: ürün inovasyonu, süreç inovasyonu, pazarlama inovasyonu ve organizasyonel inovasyondur. $\mathrm{Bu}$ bölümde de inovasyon türlerinin açıklandıktan sonra eğitim ile ilişkisi kurularak örneklendirilecektir.

\section{1. Ürün İnovasyon}

Bir ürünün var olan özelliklerinde veya öngörülen kullanımlarına göre daha yeni ve önemli derecede iyileştirme yapılmasıdır (TÜBİTAK, 2003). Kırım (2006) ürün inovasyonunu benzer bir biçimde; bir kurumun/işletmenin yeni bir ürün ortaya koyması ya da var olan ürününe farklı özellikler kazandırarak piyasaya sunulması olarak tanımlamaktadır.

Eğitim kurumlarında ürün bulunmamaktadır. Eğitim kurumlarının amacı öğrencilere topluma uyum sağlayabilmeleri için gerekli bilgi, beceri, tutum ve değerleri kazandırmak, toplumun devamlılığını sağlamak ve geliştirmektir. Ürün inovasyonu açısından öğrencilere var olandan farklı beceri, tutum ve değerlerin kazandırılması ürün inovasyonu olarak kabul edilebilir. Bu açıdan 21. yüzyıl becerilerinin kazandırılmasının amaçlanması eğitim alanında son yıllarda yapılan en önemli ürün inovasyonu olarak önerilebilir.

\section{Hizmet/Süreç Inovasyonu}

Hizmet inovasyonu, yeni veya önemli derecede iyileştirilmiş bir üretim veya teslimat yönteminin gerçekleştirilmesidir. $\mathrm{Bu}$ yenilik, teknikler, teçhizat ve/veya yazılımlarda önemli değişiklikleri içermektedir (TÜBİTAK, 2003). Eğitim sistemi başlı başına bir hizmet sektörüdür. Elçi (2009)' ye göre ise süreç inovasyonu, farklı ve yeni bir üretim ya da dağıtım yönteminin geliştirilmesi veya var olan yöntemlerin iyileştirilip daha gelişkin hale getirilmesidir.

Eğitim, sosyal devletlerin üstlendiği bir toplum hizmetidir. Bu hizmetin gerçekleştirilmesi sırasında gereksinimlere ve değişimlere bağlı olarak inovasyona ihtiyaç duyulmaktadır. Öğretmenlerin eğitim hizmetlerini öğrencilere ya da velilere daha iyi iletebilmek için yapacakları her türlü değer içeren yenilikler hizmet inovasyonu olarak değerlendirilebilir. Örneğin; MEB'in öğrencilerin devamsızlıkları, notları vb. bilgileri internet ortamında sunması, eğitimde teknoloji olanaklarının yaygınlaştırılması amacıyla yapıldığı belirtilen FATİH projesi hizmet inovasyonuna örnekler olarak gösterilebilir.

\section{Pazarlama İnovasyonu}

Pazarlama inovasyonu, ürün tasarımında veya paketinde, ürün yerleştirmede, ürün tanıtımında ya da fiyatlandırmasına önemli değişikler içeren yeni bir pazarlama yönteminin uygulanması, ya da var olanların iyileştirilerek daha gelişkin hale getirilmesidir (TÜSİAD, 2003).

Türkiye'de eğitim ile ilgili bütün kurumlar MEB'e bağlıdır ve eğitim hizmeti kamusal ve özel olarak iki biçimde gerçekleştirilmektedir. Özel hizmet veren okulların piyasa koşulları gereği daha fazla öğrenciye ulaşabilmek için sunduğu hizmeti pazarlaması gerekmektedir. Pazarlama inovasyonuna daha çok özel okulların reklamlarında karşılaşılmaktadır. Özel okullar, verdikleri burslar, ulusal sınavlardaki başarılar, okulların fiziksel koşulları ve mezunların iş bulma imkânları 
üzerinden sundukları hizmeti pazarlamaya çalışmaktadır. Genelde tek bir kampüste bulunan özel okulların büyük şehirlerde birden çok küçük kampüsler biçiminde yapılanarak öğrenci ulaşımını kolaylaştırmış olmaları bir pazarlama inovasyonu örneği olarak gösterilebilir.

\section{Organizasyonel İnovasyon}

Firmanın ticari uygulamalarında, işyeri organizasyonunda veya dış ilişkilerde yeni bir organizasyonel yöntem uygulamasıdır (TÜSİAD, 2003). Eğitim alanında organizasyonel inovasyon, eğitimin kalitesini, politikasını ve çalışma süreci geliştiren bir okul sistemi kurulmasını sağlayan sürecin geliştirilmesi olarak tanımlanabilir.

Okul işleyiş sistemini kapsaması açısından diğer inovasyon türlerini de kısmen kapsadığ söylenebilir. Örgütsel inovasyonlara en iyi örneklere özel vakıf okullarında rastlanmaktadır. Özel kurumlar olması nedeniyle eğitim öğretim süreci kendi yapısı içinde, yönetim, işletme vb. süreçler kendi yapısı içinde işlemektedir. Farklı bir organizasyon yapısı içermektedir. Kamu okullarında müdürler öğretmenler arasında atama yoluyla gelirken özel kurumlarda okul müdürünün üstünde bir yapı bulunabilmektedir. Özel okullarda, okul akademik danışmanlığı, ar-ge birimleri vb. yapıların yer alması ve eğitim-öğretim sürecine destek sağlamaları açısından organizasyonel inovasyon örnekleri olarak değerlendirilebilir.

Oslo Kılavuzu'na göre inovasyon türleri dört inovasyon türü ile sınırlıdır. Ancak alanyazında Sosyal İnovasyon, Radikal İnovasyon, Arttırımsal İnovasyon, Açık-Kapalı inovasyon türleri ile karşılaşılmaktadır.

\section{Toplumsal İnovasyon}

Toplumsal inovasyonun çıkış noktası, 20'nci yüzyılın son çeyreğinde gelişen "sosyal sorumluluk" anlayışıdır. Bugün sosyal sorumluk anlayışı toplumsal inovasyon yönünde değişim göstermiştir. Toplumsal inovasyon anlayışı ile birlikte hem firmalar hem de toplum için katma değeri yüksek ve sürdürülebilir değişim/gelişim süreci hedeflenmektedir (Banger, 2007). Toplumsal inovasyonla, toplumun ve bireylerin ekonomik, sosyal ve kültürel yaşam kalitelerinin artması özel kuruluşlara daha kalifiye işgücü, gelir artışıyla yeni pazarların ortaya çıkması olarak bir geri dönüşüm sağlayacaktır (Uzkurt, 2008).

Elçi’ye (2009) göre toplumsal inovasyon, toplumun tüm kesimlerine fayda sağlayacak yenilik, değişiklik ve iyileştirme faaliyetlerinin geliştirilmesi ve uygulanmasıdır. Toplumsal inovasyonun yaşama geçirilmesi sağlıklı ve sağlam temelleri olan toplumların kurulmasını sağlayacaktır.

İnovasyon türleri açısından eğitim sistemi ile doğrudan ilişkili olabilecek inovasyon türüdür. Yapısı gereği eğitim bireyleri çevreye uyumlarını sağlarken ileriye, çağdaşlık yolunda bir biçimde çevrelerini değiştirmelerini beklemektedir. Bu sayede toplumlar gelişim gösterebilirler. Eğitim sisteminde öğrencilerin çevrelerindeki sorunları belirleyebilmeleri ve bu sorunların çözümüne yönelik girişimlerde bulunmaları belki de eğitimin en önemli amacı olmalıdır.

Okulların kitap kampanyaları düzenleyerek kütüphanesi olmayan okullara kitap yollamaları, öğretmenlerin işe yarar uygulamalarını diğer öğretmenlerle paylaşarak öğrencinin öğrenmesini sağlaması, öğrencilerin çevreye yönelik projeler hazırlamaları ve yürütmeleri hem okul-çevre ilişkisinin güçlenmesine hem de eğitimin toplumdan kopuk olmamasına yardımcı olacak sosyal inovasyon örnekleridir. 


\section{Radikal ve Artturımsal İnovasyon}

İnovasyon örgütlerde ve çevrede bıraktığı etkiye göre, radikal ve arttırımsal inovasyon olmak üzere ikiye ayrılmaktadır. Bu inovasyon türleri diğer inovasyon türlerinin tüm boyutlarında olabilir. $\mathrm{Bu}$ açıdan daha kapsayıcı inovasyon türleridir. Radikal inovasyonda, daha önce hiç denenmemiş ürün, hizmet ya da yöntemlerin geliştirildiği radikal fikirler kullanılırken; arttırımsal inovasyonda bir dizi gelişme ve iyileştirme faaliyetlerini içeren çalışmalar takip edilir. Toplumsal inovasyonun da arrtırımsal ve radikali olur. Radikal ve arttırımsal inovasyon aslında daha büyük bir çerçevedir. $\mathrm{Bu}$ inovasyonların tümünün radikali de olur arttırımsalı da olur.

Radikal inovasyonda, müşterilerin davranışlarında önemli değişikliklere yol açan büyük ölçüde değişmiş ürünlerin ve/veya tamamen yeni ürün, hizmet ve yöntemlerin geliştirilmesi ve ekonomik faydaya dönüştürülmesi söz konusudur. Bunun dışında kalan inovasyonlar arttırımsal inovasyon olarak değerlendirilir (Elçi, 2009).

Radikal inovasyonlar riski ve maliyeti yüksek, başarı şansı başarısılı̆ı̆ına göre daha az ve sürecin oldukça belirsiz ve uzun olduğu inovasyonlardır. Yüksek oranda riskli oldukları ve büyük araştırma maliyetleri getirdikleri için radikal inovasyonlara karar verilirken işletmelerin çok dikkatli olmaları gerekmektedir. Ancak başarıya ulaşıldığında firma hem ilk olmanın avantajını yaşamakta, hem de rekabet gücünü o derece pekiştirmektedir. Radikal inovasyonlar tamamen yeni mamul ya da hizmet kategorilerini ya da üretim ve dağıtım sistemlerini içerirken, arttırımsal inovasyonlar mevcut mamuller ve hizmetler ya da üretim ve dağıtım sistemlerinin geliştirilmesini içerir (Güleş ve Bülbül, 2004).

Radikal inovasyon riskli bir iştir. Radikal inovasyonun yaşam döngüleri uzundur, başlangıç ve bitişi tahmin edilemezdir, bağımlı-bağımsız stratejik noktaları artan, ilerlemeyen veya biten bir gelişme gösterir ve genellikle çapraz-fonksiyonel takımlarının çalışmalarıyla gerçekleştirilir (Keizer ve Hamlan'dan aktaran Karabulut, 2009).

\section{Açık ve Kapalı Ínovasyonlar}

Açık ve kapalı inovasyondan kastedilen nokta inovasyonun kurum içi ya da kurum dışında başka ortaklarla gerçekleştirilmesidir. Eğer kurum inovasyonu kendi olanakları ile gerçekleştirirse bu bir kapalı inovasyondur ancak kurum inovasyon için dışarıdan uzmanlık vb. biçimde destek alırsa açık inovasyondur.

Eğitim sistemi açısından açık ve kapalı inovasyon şu şekilde örneklendirilebilir: Öğrenmeöğretme sürecini yazılımlar kullanarak teknolojik açıdan desteklemek isteyen bir okul bu yazılımları kendi içinde bulunan öğretmenlerin yardımı ile geliştirirse kapalı inovasyon gerçekleştirmiş olur. Eğer öğretmelerin bu hizmeti sunacak teknolojik alt yapıları yoksa bunun için bir yazılım firmasından hizmet satın alma yoluna gidebilir. Yazılım şirketinin öğretmenlerin istekleri doğrultusunda hazırlamış oldukları materyaller öğretmenler tarafından kullanıldığı zaman hem açık hem de süreç inovasyonu olarak nitelendirilebilir.

İnovasyonun gerçekleşmesi için yaratıc1lıkta olduğu gibi bir süreç izlenmektedir. Bu süreç sonunda yukarıda açıklanan inovasyon türleri gerçekleştirilmektedir. 


\section{İnovasyon Süreci}

İnovasyon süreci, yaratıcı düşünce ürünü olarak ortaya çıkmış fikir ya da ürünün değer elde ettiği ana kadar geçirmiş̧ olduğu süreci kapsamaktadır. Elçi (2009) inovasyon döngüsünü şu şekilde şemalandırmıştır:

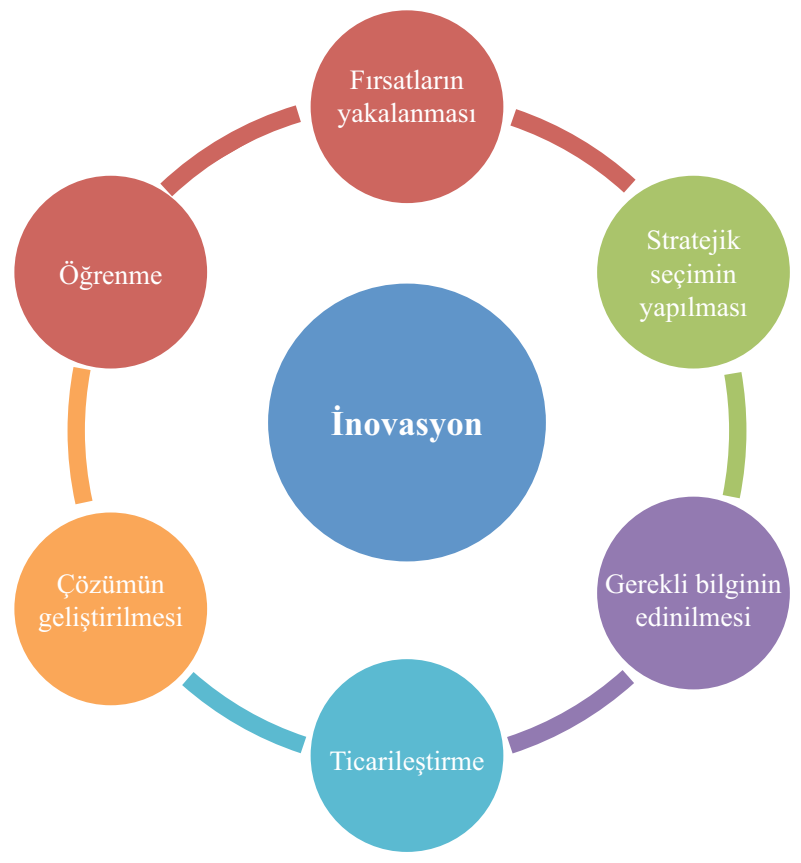

Şekil 1. İnovasyon Döngüsü

İnovasyon döngüsü eğitim alanında şu şekilde somutlaştırılabilir:

İnovasyonun başlangıç noktası inovasyon için gerekli fikirlerin bulunmasıdır. Bu nedenle inovasyon kaynakları yakından takip edilmelidir. Öğretmen, öğrenci, veli, yönetici olmak üzere eğitim paydaşlarının sürekli bir biçimde iletişim halinde olmasını gerektirir. Örneğin; herhangi bir derste öğrencilerin öğrenme güçlüğü yaşadığı konuların belirlenmesi ve öğrencilerin öğrenmelerinin sağlanması için yapılacak çalışmalar birer inovasyon haline getirilebilir.

Belirlenen firsatlardan hangisinin stratejik açıdan daha önemli olduğu belirlenmeye çalışılır. $\mathrm{Bu}$ aşamada eğitim paydaşlarının gereksinimleri ve istekleri göz önünde bulundurulmalıdır. Öğrencilerin bu konuyu öğrenmeleri için yazılımlar geliştirilebilir ya da eğitsel bir oyun konu ile ilişkilendirilerek bir ders tasarımı yapılabilir.

Belirlenen inovasyon fikrinin yaşama geçirilmesi için gerekli bilgilerin toplanması faydamaliyet analizlerinin yapılması gerekmektedir. Konunun öğretilmesi için kullanılabilecek bir yazılım için farklı uzmanlık alanlarından destek alınması gerekebilir buna karşı eğitsel bir oyunda öğrencinin konu ile oyun arasındaki ilişkiyi kurabilmesi zor olabilir.

Konunun öğretilmesi için en iyi yolunda yazılım hazırlamak kararı verildikten sonra yazılım hazırlanması için öğretmen ve yazılım uzmanı bir araya gelerek öğretim materyalini hazırlayabilir. Hazırlanan ürün sınıflarda uygulanır ve öğrencilerin öğrenme düzeyleri tekrar ölçülerek ürünün etkisi test edilmeye çalışılır. Geliştirilen materyal sosyal paylaşım ortamlarında farklı okullardaki öğretmenlerin kullanımına sunulabilir. Bu durum ücretli olabileceği gibi sadece sosyal inovasyon 
olarak ücret yerine sosyal değer atfederek gerçekleştirilebilir. Farklı okullardaki öğretmenlerin uygulama sonuçlarının paylaşılması ile ürün üzerinde varsa geliştirme etkinliklerine devam edilebilir.

\section{Sonuç ve Öneriler}

Dördüncü sanayi devrimi ülkeler arasındaki ekonomik rekabeti farklı bir boyuta taşımıştır. Ülkeler ekonomilerini, inovasyona dayalı ekonomiler haline getirmek zorunda kalmaktadır. İnovasyona dayalı ekonomiler özellikle yaratıcılık, yaratıcı düşünme gibi özellikleri gelişmiş bireylere gereksinim duymaktadır. Bu gereksinimin karşılanması ise öncelikle eğitim sistemlerinin görevleridir. Eğitim sistemleri inovatif düşünen bireyleri yetiştirmeyi amaçlarken hem ekonomik hem de teknolojik alandaki gelişmelerden de doğrudan etkilenmektedir. Bu etkilenme eğitim sisteminin kendi içinde inovasyonlar yapmalarını zorunlu kılmaktadır. Ancak inovasyon kavramının yanlış algılanması yanlış uygulamaların yaşama geçirilmesine neden olmaktadır. İnovasyon olduğu düşünülen yenilikler herhangi bir değer taşımamakta hatta gelişmeden çok geri götürmektedir. Örneğin; Herhangi bir pilot uygulama yapılmadan, gerekli alt yapı hazırlıkları gerçekleştirilmeden 2012 yılında kabul edilen 4+4+4 kademeli eğitim sistemi ve 60 aylık çocukların eğitim sürecine alınmaları bir yenilik olmasına rağmen eğitim sisteminde olumsuz etkilere neden olmuştur.

Önceki sanayi devrimlerini geriden takip etmiş Türkiye için dördüncü sanayi devrimi hem bir firsat hem de bir risktir. Bu sanayi devrimi de kaçırıldığı takdirde ekonomik olarak rekabet edebilir bir ülke olmaktan öte ara eleman yetiştiren bir ülke konumuna düşecektir. Diğer taraftan inovasyona dayalı bir ekonomi ile dördüncü sanayi devrimi yakalanabilir ve refah düzeyi gelişmiş bir ülke hedefi yakalanabilir.

2004 yılında gerçekleştirilen eğitim reformunda yaratıcı düşünme becerisi tüm öğretim programlarında geliştirilmesi beklenen temel becerilerden birisi olmuştur. Ayrıca inovasyonu geliştirmeye yönelik olarak Teknoloji ve Tasarım dersleri okul programları arasına konulmuştur. MEB tarafından bu inovasyonlar yaşama geçirilirken alınan sonuçlar istenilen hedeflere ulaşılmadığını göstermektedir. 2015 yılı PISA uygulamaları sonucunda Türkiye 2012 yılında yakaladığı başarının gerisine düşmüştür.

Eğitim sistemlerinde özellikle sosyal inovasyonların gerçekleştirilmesi, bu inovasyonların süreklilik arz etmesi gerekmektedir. Gerçekleştirilen inovasyonların gerekli alt yapı çalışmaları yapılmadan yaşama geçirilmesi ve paydaşlar arasında gerekli işbirliğiinin en iyi biçimde sağlanması önem arz etmektedir. 


\section{Kaynakça}

21st Century Skills. (2016). http://www.p21.org/our-work/p21-framework sayfasından erişilmiştir.

Amabile,T. M. (1997). Motivating creativity in organizations: On doing what you love and loving what you do. California Management Review, 40(1), 39-58.

Aish, D. (2014). Teachers'beliefs about creativity in the elementary classroom. Doctoral Dissertation, Pepperdine University Graduate School of Education and Psychology, USA.

Ayob, A., Hussain, A, \& Majid, R. A. (2013). A review of research on creative teachers in higher education. International Education Sciences. 6(6), 8-14.

Baykal, B. (2007). İnovasyon ve sürdürülebilir kalkınma ilişkisi: Türkiye. Yüksek Lisans Tezi, Marmara Üniversitesi Sosyal Bilimler Enstitüsü, İstanbul.

Bentley, T. (2003). Learning beyond the classroom. London: Routledge.

Burnard, P., \& White, J. (2008). Creativity and performatvity: counterpoints in British and Australian education. British Educational Research Journal, 34(5), 667-682. doi:10.1080/01411920802224238

Craft, A. (2007). Creativity in education. USA: Continuum.

Drucker, F., B. (1998). The disipline of innovation. HArward Business Review. https://pdfs.semanticscholar. org/e5f5/7b14cb587f69534565473c64062fe0b4bce6.pdf adresinden indirilmiştir.

Edvinsson, L., Dvir, R., Roth, N., \& Pasher, E. (2004). Innovations: the new unit of analysis in the knowledge era. Journal of Intellectual Capital, 5(1), 41-52.

Elçi, Ș. (2009). İnovasyon kalkınmanın ve rekabetin anahtarı. Ankara: Technopolis. Ersöz, F. (2009). Avrupa inovasyon göstergeleri (EIS) 1şığında Türkiye'nin konumu. İTÜ Dergisi, 1, 3-16.

Eryılmaz, S. \& Uluyol, Ç. (2015). 21. Yüzyıl becerileri ışı̆̆ında FATİH projesi değerlendirmesi. Gazi Üniversitesi Eğitim Fakültesi Dergisi, 35(2), 209-229.

Fisher, R. (2004). Creativity across the curriculum. R. Fisher \& M. Williams (Eds.), Unlocking creativity içinde (s. 160-172). Britain: David Fulton.

Florida, R. (2010). The flight of the creative class: the new global competition for talent. USA: Collins.

Güleş, H., K. \& Bülbül, H. (2004). Yenilikçilik, işletmeler için stratejik rekabet aracı. Ankara: Nobel.

Işık, C., \& Keskin, G. (2013). Bilgi ekonomilerinde rekabet üstünlüğü oluşturulması açısından inovasyonun önemi. Atatürk Üniversitesi İktisadi ve İdari Bilimler Dergisi, 27(1), 41-57.

Işık, N., \& Kılınç, E., C. (2012). İnovasyon-temelli ekonomi: seçilmiş ülkeler üzerine bir uygulama. Anadolu Üniversitesi Sosyal Bilimler Dergisi, 16(1), 13-28.

Kampylis, P. G. (2010). Fostering creative thinking: the role of primary teachers. Finland.

Karabulut, S. (2009). Ürün geliştirme takımlarında yaratıcılık ve yenilik yönetimi. Yüksek lisans tezi, Gebze Yüksek Teknoloji Enstitüsü, Gebze.

Kavacık, L. (2012). İlköğretim altıncı sınıf fen ve teknoloji dersi madde ve 1s1 ünitesi grupla yenilikçi (inovasyon) projeler oluşturmanın öğrenciler üzerine etkisi. Yüksek Lisans Tezi, Mersin Üniversitesi Eğitim Bilimleri Enstitüsü, Mersin.

Kılınç, E. C. (2011). İnovasyon ve ulusal kalkınma: AB ülkeleri ve Türkiye üzerine bir inceleme. Yüksek Lisans Tezi, Karamanoğlu Mehmet Bey Üniversitesi Sosyal Bilimler Enstitüsü, Karaman.

Kırım, A. (2006). Farklılaşmanin en etkin yolu, deneyim inovasyonu. İstanbul: Sistem.

Kırım, A. (2009). Arman Kırım'dan inovasyon dersleri. İstanbul: Om.

Kurtuluş, M. F. (2012). Eğitimde inovasyon: öğretmen ve öğrencilerin inovasyona bakışl ve yeterliliğinin sorgulanması. Yüksek Lisans Tezi, Gebze İleri Teknoloji Enstitüsü, Gebze.

Lau, J. Y. (2011). An introduction to critical thinking and creativity: Think more, think better. John Wiley \& Sons. 
Lubienski, C. (2009), "Do Quasi-markets Foster Innovation in Education?: A Comparative Perspective", OECD Education Working Papers, No. 25, OECD Publishing. http://dx.doi.org/10.1787/221583463325

Luecke R., (2008). İs dünyasında yenilik ve yaratıcıllı (T. Parlak, Çev.). İstanbul: İş Bankası.

Pacific Policy Research Center. (2010). 21st century skills for students and teachers. Honolulu: Kamehameha Schools, Research \& Evaluation Division.

Porter, M. (1990). The competitive advantage of nations. Newyork: Free.

Rank, J., Pace V. L., \& Frese M. (2004). Three avenues for future research on creativity, innovation, and initiative. Applied Psychology: An International Review, 53(4), 518-528.

Robinson, K. (2008). Yaratıcılık aklın sinırlarını aşmak. (N. G. Koldaş, Çev.). İstanbul: Kitap.

San, İ. (2008). Yaratıcılıkta temel kavramlar. A. Öztürk (Ed.), Okul öncesinde yaratıcılık ve drama eğitimi. (s. 1-15). Eskişehir: Anadolu Üniversitesi.

Shqipe, G.,\& Ramadani, V., (2010), The Impact of innovation into the economic growth, http:// mpra.ub.uni-muenchen.de/22270 adresinden erişilmiştir.

Tanner, D. (1994). Creativity and innovation in R\&D. R\&D Innovator, 3(7), 101-150.

Ten Skills. (2016). https://www.weforum.org/agenda/2016/01/the-10-skills-you-need-to-thrive-in-the-fourth-industrial-revolution/ adresinden erişilmiştir.

Torrance, E. P. (1995). Why fly?. Greenwood.

Türkiye Sanayicileri ve İşadamları Derneği (2003). Ulusal inovasyon sistemi, kavramsal çerçeve, Türkiye incelemesi ve ülke örnekleri. http://www.tusiad.org/tr/yayinlar/raporlar/item/1904-ulusal-inovasyon-sistemi sayfasından erişilmiştir.

Uzkurt, C. (2008). Yenilik yönetimi ve yenilikçi örgüt kültürü. İstanbul: Beta.

Wagner, T. (2008). The global achievement gap: Why even our best schools don't teach the new survival skills our children need - and what we can do about it. New York: Basic.

Zeren, D. (2010). Mobil hizmet inovasyonlarının kabulü: Türkiye örneği. Doktora tezi, Çukurova Üniversitesi, Sosyal Bilimler Enstitüsü, Adana. 
